\title{
The Argentine Precordillera
}

\section{as a key to Andean Structure}

\author{
by B. Baldis, M. Beresi, O. Bordonaro and A. Vaca
}

\begin{abstract}
Although the Argentine Precordillera is only $400 \mathrm{~km}$ long it is a key zone for studying the genesis of the Andes. It is located in the transitional zone between the Pampean craton and the mobile belt of the Pacific edge of South America. This article summarizes recent studies on the Precordillera, with emphasis on its Paleozoic evolution and its significance to the development of the Pacific Ocean margin of southernmost South America.

Introduction
\end{abstract}

The $400 \mathrm{~km}$ long Precordillera is unique throughout the Andes (Fig. 2) because it contains a complete thick sequence of Early Paleozoic rocks closely linked to the foreland craton and exposed by the tectonic movements which created the Andes. Work done over the last decade has led to an understanding of the structure of the Precordillera and neighbouring areas, as well as to an appreciation of the role these rocks have played in the genesis of the mobile side of South America during the Paleozoic.

Much of this work has been carried out within the framework of the International Geological Correlation Programme, specifically IGCP Projects 44 (Lower Paleozoic of South America-completed), 192 (Cambro-Ordovician), 193 (Siluro-Devonian) and 202 (Mega-faults).

Project 192 is especially important because its objective is to analyse the development of post-Precambrian continental margins. In Argentina, detailed studies have been conducted on the different stratigraphic sequences of the Precordillera, and satellite images have been used to interpret structures. This work has led to new ideas about the genesis and evolution of the Precordillera sedimentary basins and their relation to the lineaments and fracture zones present in the basement.

Working conditions in the Precordillera are not easy. It is located in the arid triangle of South America, and its mountain ranges are high and relatively inaccessible. From the standpoint of both climate and landscape, the Precordillera region resembles parts of the southwestern United States, including the Death Valley region.

Evolution of the Paleozoic Basins

The Precordillera contains a thick column of Paleozoic rocks (Fig. 1) actively controlled by a rigid, tectonically stable foundation. This geological province is bounded to the east by the Pampean Ranges, which constituted a stable foreland during the Paleozoic. To the north it ends against the Puna, a high plateau closely linked with the Arequipa massif of Peru. The western border of the Precordillera is marked by the "Cordillera Frontal" and the "Cordillera Principal" belts of Andean structure accreted to the Precordillera. Jordan and others (1983) presented a general view of the deep structure of this part of the Andes, relating the Precordillera to the flat-subduction segment of the chain.

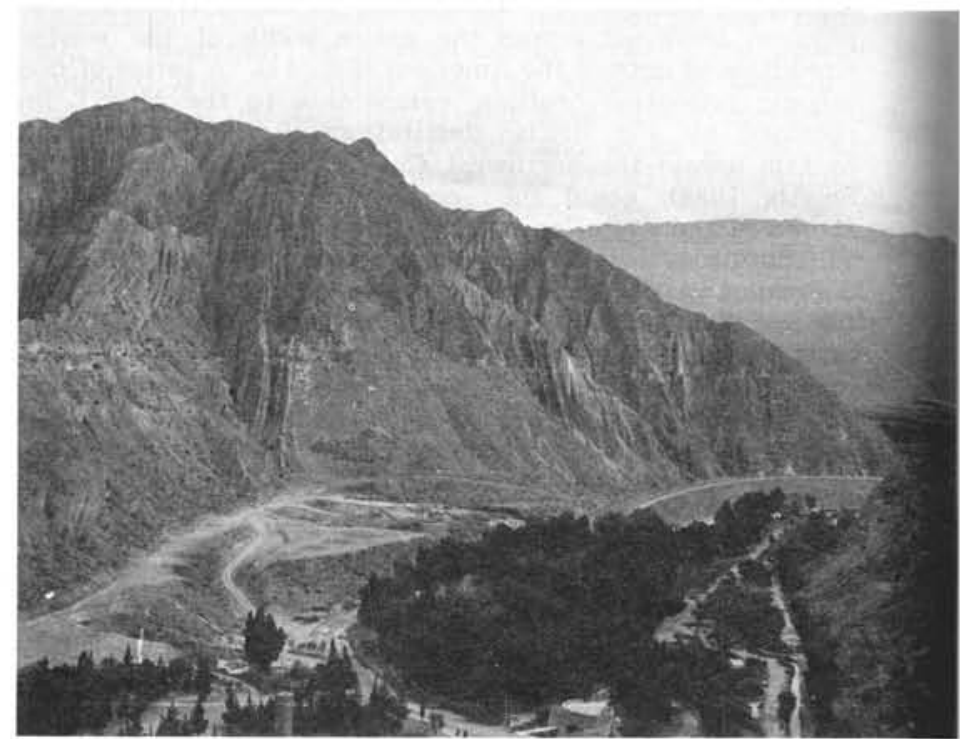

Figure 1: Cambrian limestones of the Zonda Valley in the eastern Precordillera.

Along the entire western edge of South America the mountain chains making up the Andean Cordillera are separated from the ancient cratonic landmasses by two well-differentiated elements: small chains that lean like foothills directly against the eastern flank of the Cordillera, and depressed areas located to the east of the foothills. The small chains are exemplified by the sub-Andean belt that extends from Peru to northern Argentina, and the fold-thrust belt that runs from the southern edge of the Puna to the northern Patagonian landmass, entirely in Argentina (Fig 2). The sub-Andean belt forms a transitional system between the orogenic Andes area and the broad plains, with a block-type structure that separates them from the continental shields outcroping eastwards in the heart of South America.

The Precordillera (Fig. 3) is a geological province elongated north-south and located between the Andes belt to the west and the blocks of the Central Argentine Craton to the east (Bracaccini, 1960). It consists of three well-defined longitudinal belts: an eastern belt of overthrusts controlled by Cambrian and Ordovician limestone; a central zone made up of the Tontal-Tigre-Punilla Paleozoic block; and a western belt characterized by a sharp mid-Devonian deformation and metamorphism together with earlier (Ordovician-Devonian) basaltic magmatism (Baldis et al., 1982). An analysis of the structural evolution of the successor basins shows that the structure of the Precordillera was basement controlled. In the following, the paleogeographic setting of the Precordillera is reviewed at different stages during its evolution (Figs. 4 and 5). 
a warm climate during the Lower Silurian in the region from Peru to Patagonia. The higher Silurian deposits of the central Precordillera include macrofossils, graptolites (Monograptus) and an association of acritarchs, indicating Wenlockian and Ludlovian ages and the transgressive nature of the Silurian sea.

In the Silurian basin of the central Precordillera rapid subsidence occurred. Zoophicus is found here above the iron-bearing levels, indicating an epicontinental neritic environment changing upwards to layers of Nereities in a turbidite environment and perhaps pre-geosynclinal facies. In the Upper Silurian a slow regressive process is indicated by the presence of ripple marks and coquinas over an extensive region. An unstable platform environment here ended the depositional cycle, while in the western Precordillera a lateral facies of bathyal environment is assumed to have existed towards the open sea.

The end of this slow regressive process is indicated in the base of the Upper Silurian, which is characterized by a shallow water regime and an unstable platform. The interruption of this regression marked the end of the Silurian period. After this time, and with a possible diastem for the Gedinnian, Devonian deposition began with levels of Lingula lepta and an association of Malvinokafric brachiopods characteristic of the Lower Devonian. Homalonotus is also present, thereby constituting the "Lingula community" (Copper, 1977). Thus it appears that a general change occurred at the Silurian-Devonian boundary in the Precordillera basement.

\section{The Devonian Basin}

The Devonian of the Precordillera is represented by two well-differentiated sedimentary stages. The first exhibits the characteristics of a stable platform; the last stage is represented by a thick accumulation of terrigenous sediments (wackes and shales) arranged in large submarine fans deposited under constantly turbid conditions. The formation of these fans was controlled by two limiting highs, one internal (the Zonda High) and one external (the Tontal High or Proto-precordillera).

Paleontological studies indicate that for the central sector of the Precordillera, the Lower Devonian clearly contains Malvinokafric Favosites, Notiochonetes and Australospirifer, while in the northern Precordillera the fauna is composed of the Middle Devonian trilobites Cryphaeoides and Acanthopyge. The latter association, together with their equivalents in the basins of northeastern Argentina and Bolivia (Tarija and Sica-Sica), suggest the presence in the central Andes of a faunal province that is different from the classical Malvinokafric province (Baldis, 1979).

\section{The Carboniferous and Permian Basin}

There is a clear stratigraphic hiatus in the Precordillera between the Upper Devonian and the Carboniferous, as can be seen from the strong angular unconformity on both sides of the Precordillera; in the central Precordillera there is an apparent conformity. This situation reflects the presence in the Devonian of the Tontal and Zonda Highs.

The Tontal High, which was already apparent as an emerged area, controlled sedimentation by acting as a barrier in the Carboniferous to incursions of the Pacific Sea. Thus to the west there was marine sedimentation while continental conditions prevailed in the east (Rolleri and Baldis, 1967). To the north and south, the Tontal High decreased in altitude and was covered by the Carboniferous Sea, which reached the regions of Jachal and Mendoza.

The continental units of the Carboniferous and Permian belong to the Paganzo Group, and they are characterized by

Figure 3: The Precordillera: ERTS imagery and main structural elements.
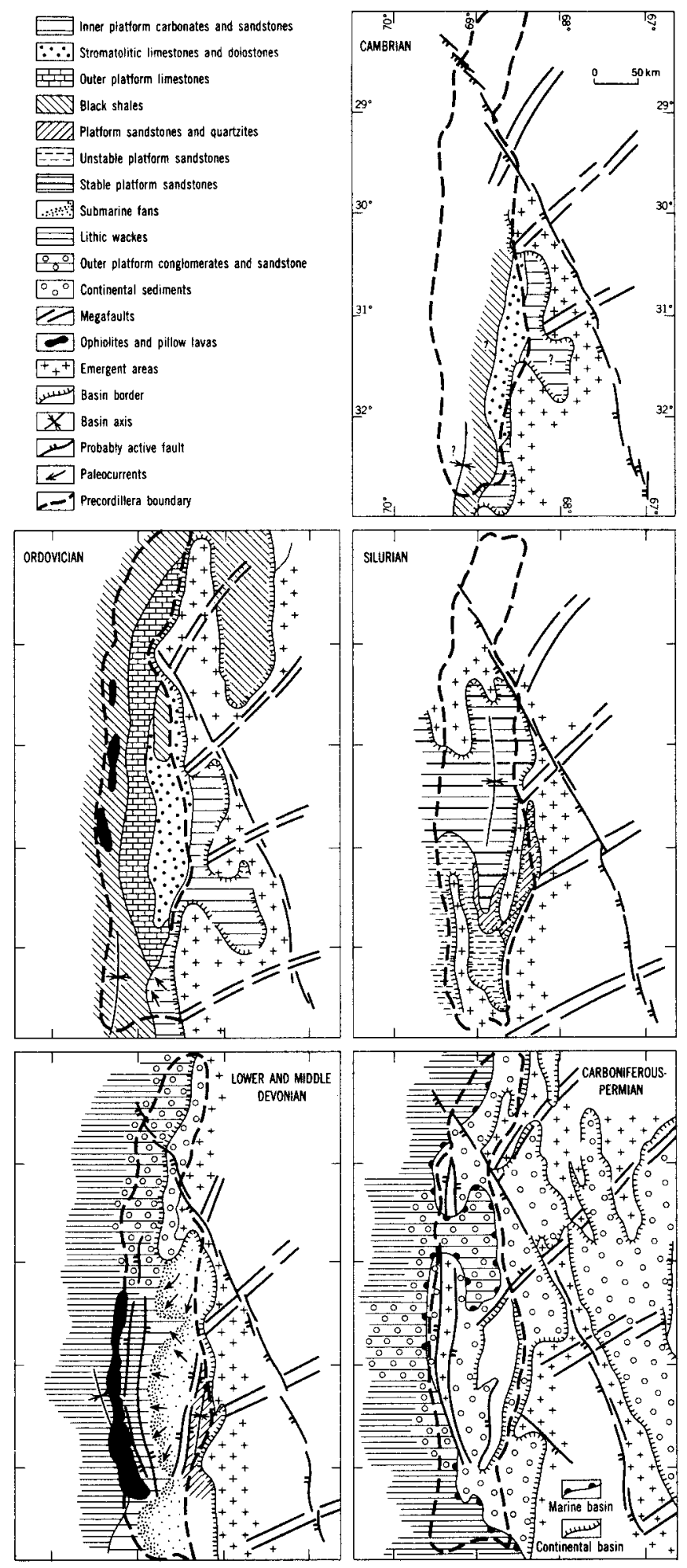

Figure 4: Paleogeographic development of the Precordillera (based on Baldis et al., 1982).

typical Gondwana flora, Rhacopteris and Glossopteris. In contrast, the marine lands of the western Precordillera are rich in brachiopods, gastropods and bivalves typical of the Carboniferous. These are overlain by continental sediments of Permian age that covered the entire Precordillera and marked a phase of continental sedimentation which has continued to the Present. 


\section{The Mesozoic Basins}

For a lange part of the Mesozoic, the Precordillera acted as a positive area and provided the source of sediments in the extensive basins that developed on its margins. Thus, during the Triassic, the central and part of the eastern Precordillera were emergent areas that contributed sediments to two large depressed regions coinciding with the present valleys of Barreal-Uspallata and Bermejo-Mendoza. Small unconnected basins formed in these areas, with typical lake and river sedimentation and environments suitable for the spread of the classical Dicroidium flora and large numbers of reptiles.

The main basins are located in the Western and Mendoza Precordillera, in the Barreal-Uspallata-Potrerillos Valleys (Stipanicic, 1979). Their paleoenvironments were suitable for the creation of coal, bitumen, oil and gas; indeed there is now much petroleum exploration activity here. The Ischigualasto basin, on the other hand, in the zone where the Precordillera joins the Pampean Range is paleontologically important because of the lange numbers of mammal-like reptiles found there.

The absence of Jurassic and Cretaceous sediments in the Precordillera indicates that the Precordillera region was elevated at this time, serving as a source area for the Bermejo and Uspallata basins. The new aetive margin was loeated to the west, eorresponding to the present-day trench of the Cordilleran belt, and closely related to the magmatic and tectonic activity of the Cordillera Prineipal of San Juan and Mendoze.

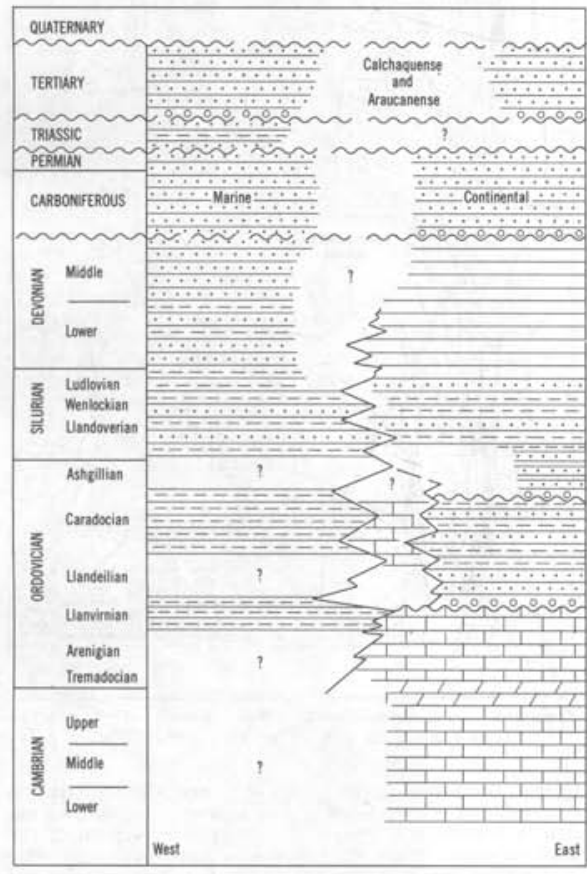

Figure 5: Simplified stratigraphic column for the Precordillera. Not to scale.
Against the Pampean Ranges to the east, a Late Jurassic to Early Cretaceous continental basin, which contains interesting pterodactyls, evolved in depositional continuity with the Triassic.

\section{The Tertiary Basin}

The rocks of the Precordillera Tertiary are predominantly clasties of continental origin, with less extensive extrusives and subvoleanics. The main feature of these Tertiary rocks is their distribution in "intra-Precordillera" basins, with variable accumulations of sediments ranging in thickness from a few hundreds to several thousands of metres. Most of the rocks from this period belong to the "Calchaquense" and "Araucanense" (Fig. 5), generally attributed to the Pliocene (Yrigoyen, 1969). Fluvial deposits predominate, though laeustrine interealations and pyroelasties are also common.

Some units are outstanding because of their mammalian fossil content (predominantly rodents) that have been used to determine biostratigraphic ages (Paseual and Odreman Rivas, 1971). Along the entire eastern seetor of the Precordillera, the Tertiary appears erowned by a thick layer of Upper Pliocene and Lower Pleistocene conglomerates (Mogna and Mogotes Formations) made up of elasts from the Precordillera and Cordillera and indicating the last stages of the rise of the Cordillera as a whole.

\section{The Structural Evolution of the Precordillera}

The regional geotectonic picture at the beginning of the Paleozoic was characterized for the Precordillera zone by a eratonic edge open to the west (the Panthalassa Sea) that behaved as a stable marine platform from the Cambrian to the Devonian. The western edge rifted away to become an elongated trench located 15 to $40 \mathrm{~km}$ from the rigid front of the craton. From the latest Devonian to the Early Carboniferous there was a tectonic event that raised the continental edge and joined the area to the rigid central Argentine nucleus. The present structural style of the Precordillera is thus the result of an almost direct eollision between the Andean belt and the rigid elements of the craton. No depression existed here to absorb these compressive stresses, as did the depressions of the northern Argentine and the Peruvian-Bolivian sectors discussed below.

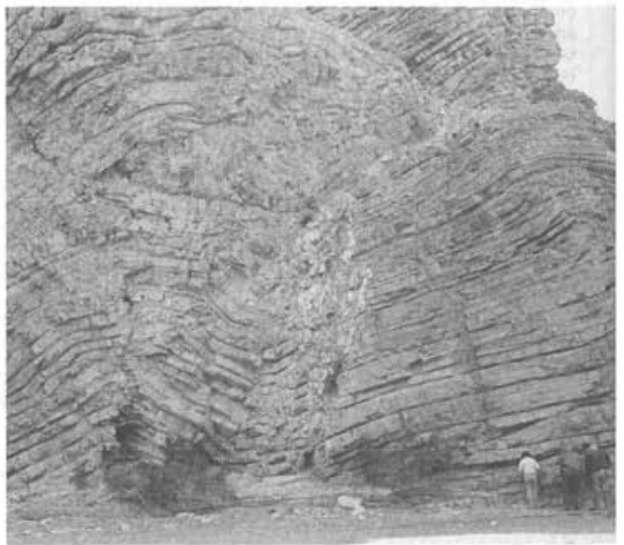

Figure 6: Arenigian sediments in the Talacasto Chasm of the central Precordillera, deformed by Late Tertiary Andean movements. 
The Precordillera and the Andean Belt

The belt that extends to the south of the Puna resembles the sub-Andean zone, in the continuing westward inclination and vergence of the main folds and fractures as opposed to those of the central Andes. There are also distinctive characteristics to these pre-Andean zones, each of which constitutes a relatively homogeneous structural region from northern Peru to Patagonia in Argentina (Baldis and Vaca, 1981).

The Andean, pre-Andean and sub-Andean areas are linked to the genesis of the cordillera as a whole. They exhibit not only regional structures created by global tectonic processes, but also strongly deformed units from smaller unstable areas such as the Precordillera (Fig. 6) and the eastern Andes, mainly of Palaeozoic age and already defined in preGondwanan and Gondwanan stages.

The Argentine and Brazilian cratons are clearly separated from one another, and there are also basins between these cratons and the Andean belts. These depressions, which are very extensive in the Peruvian-Bolivian region and also in the north of Argentina, shrink to a minimum width towards the south of the Argentine Precordillera. Here the central Argentine craton almost comes into direct contact with the Andes belt, with the Precordillera reduced to a long narrow transitional strip between them. Farther south, where the Precordillera is lost below a Triassic cover, the main blocks of the central craton are located farther to the east, and the depressed areas become wider again. However, the structural style is maintained towards the south until it collides with the transcontinental belt of megashears along the northern edge of Patagonia (Fig. 2).

\section{Summary}

Recent studies have identified the Precordillera as a unique part of the Andean region because of its tectonic style, which is strongly influenced by proximity to the craton. An almost complete sequence here of Paleozoic platform sediments permits the identification of the Early Paleozoic margin of ancient Pangaea, as well as a detailed reconstruction of paleobiological events, represented by trilobites, graptolites and abundant shelly fauna.

The position of the Precordillera along the peri-cratonic margin raises some fundamental questions. What was the relationship in the Early Paleozoic between the North and South American carbonate platforms? What were the migration patterns among South America and northern Africa and Europe? What was the precise timing of the tremendous paleogeographic changes that formed Gondwanaland? And where was the pre-Andean basement now in contact with the Precordillera? These and many other questions will form the focus in the coming years for IGCP Project 192.
Dr. Bruno A.J. Baldis is head of the Department of Geology of the National University of Buenos Aires and Coordinator of Stratigraphic Research at the National University of San Juan. He is a specialist in the Lower Paleozoic of Argentina and the author of 70 papers on the subject. He is co-leader of IGCP Project 192 and a founding member of the Ordovician Subcommission.

Alejandro Vaca, is a member of the staff of the Argentinian Regional Groundwater Centre and a professor at the National University of San Juan. He has worked on the role of megafaults in Andean geotectonics and on variations in subduction at great distances from the Pacific edge.

\section{References}

Aitken, J.D., 1966. Middle Cambrian to Middle Ordovician Cyclic Sedimentation, Southern Rocky Mountains of Alberta. Bulletin, Canadian Petroleum Geology, v. 14, no. 4 , p. 405-441.

Baldis, B.A.J. 1979. Paleozoogeografía de los trilobites devónicos en Sudamérica austral. Ameghinians, v. 16 no. 3-4, p. 209-216.

Baldis, B.A.J. and Beresi, M., 1981. Biofacies de culminación del ciclo deposicional calcáreo del Arenigiano en el oeste de Argentina. Anais do II Congreso Latinoamericano de Paleontológica, Brazil, v. 2, p. 11-16.

Baldis, B.A.J., Beresi, M.S., Bordonaro, O.L. and Uliarte, Eof Sanguinetti, Y.T. (ed.), 1981b. Estromatolitos, trombolitos y formas afines en el límite Cámbrico-Ordovieico Paleontológica, Brazil, v. 1, p. 19-30.

Baldis, B.A.J., Beresi, M.S., Bordonaro, O. and Vaca, A., 1982. Síntesis evolutiva de la Precordillera angentina. Actas V Congreso Latimoamericano de Geológia, Buenos Aires, Argentins, v. IV, p. 399-445.

Baldis, B.A.J. and Bordonaro, O., 1981. Evolución de facies carbonáticas en la cuenca cámbrica de la Precordillera de San Juan.

Baldis, B.A.J. and Bordonaro, O., 1982. Comparación entre el Cámbrico de la "Great Basin" norteamericana y la Pre-
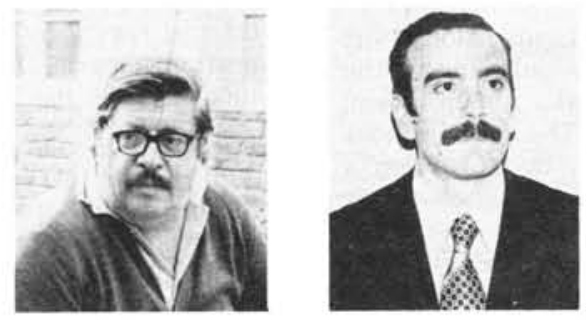

Dr. Osvaldo Bordonaro, a researcher with CONICET (the National Scientific and Technical Research Council of Argentina) and a professor at the National University of San Juan, has been a leader in recent studies on the Cambrian of the Argentine Precordillera. His interests include trilobites and their relation to cyclic sedimentation on Carboniferous platforms.
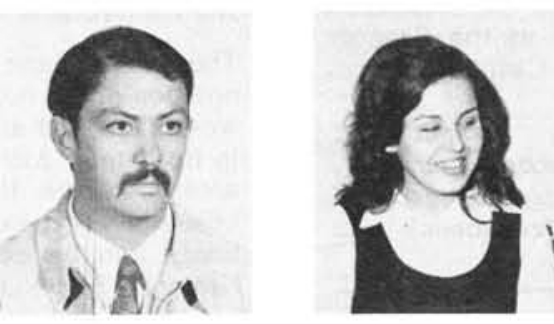

Matilde S. Beresi is also a researcher with CONICET and professor at the University of San Juan. She specializes in the stratigraphy of the Argentine Ordovician, with interests in paleoecology and biofacies of limestone sequences.

cordillera de San Juan, Argentina, su implicancia intercontinental. Actas V Congreso Latinoamericano de Geológia, Buenos Aires, Argentina, v. 1, p. 97-108.

Baldis, B.A.J., Bordonaro, O., Beresi, M. and Uliarte, E., 1981a. Zona de dispersión estromatolítica en la secuenci calcáreo-dolomítica de Paleozoico Inferior de San Juan. VIII Congreso Geológico Argentino. Actas 11, p. 419-434.

Baldis, B.A.J, and Vaca, A., 1981. E1 Sistema Preandino de Sudamérica Central como zona antitética de respuestas a la Deriva continental. VIII Congreso Geológico Argentino, IV: $211-222$.

Bordonaro, O., 1980. El Cámbrico en la Quebbrada de Zonda, Provincia de San Juan. Revista de la Asociación Geológica Argentina. v. 35 , no. 1, p. 26-40.

Bracaccini, O.L., 1960. Lineamientos principales de la evolución estructural de la Argentina. Petrotecnia, X(6), Buenos Aires.

Copper, P. 1977. Paleolatitudes in the Devonian of Brazil and the Frasnian-Famennian mass extinction. Palaeogeography, Palaeoclimatology and Palaeoecology, v. 21 no. 3, p. 165-207.

Fortey, R.A., 1975. Early Ordovieian trilobite communities. Fossils and Strata, no. 4, p. 331-352.

Furque, G. and Cuerda, A.J., 1979. Precordillera de La Rioja, San Juan y Mendoza. In Segundo Simposio de Geo- lógia Regional Argentina, v. I, Academia Nacional de Cieneias de Córdoba, Argentina, v. 1, p. 455-522.

Jordan, T.E., Isacks, B.L., Ramos, V.A. and Allmendinger, R.W., 1983. Mountain building in the Central Andes. Episodes $1983 / 3$, p. $20-26$.

Palmer, A.R. and Taylor, M.E. (eds.), 1981. On the correlatability of Grand Cyele tops. II International Symposium on the Cambrian System, Golden, Colorado, Aug $9-13$, 1981, U.S. Geological Survey Open File Report 81-0743, p. 156-159.

Pascual, R. and Odreman Rivas, O.E., 1971. Evolucion de las comunidades de los vertebrados del Tertiario Argentino: lacionados. Ameghiniana, v. 8, p. 372-412.

Rolleri, E.O. and Baldis, B.A.J., 1967. Paleogeography and distribution of carboniferous deposits in the Argentine Precordillera. Coloquio de la UICG: La estratigrafía del Gondwans, (2): 1005-1024. Unesco, 1969.

Stipanicic, P.N., 1979. El Triásico del valle del Río de Los Patos (Provincia de San Juan). In: Segundo Simposio de Geológia Regional Argentina, Academia Nacional de Ciencias de Córdoba, Argentina, li p. 695-744.

Yrigoyen, M.R., 1969. Problemas estratigráficos del Terciario de Argentina. Ameghiniana, v. 6, no. 4, p. 315-329. 